\title{
Foliar stable isotope ratios of carbon and nitrogen in boreal forest plants exposed to long-term pollution from the nickel-copper smelter at Monchegorsk, Russia
}

\author{
Sirkku Manninen ${ }^{1} \cdot$ Vitali Zverev $^{2} \cdot$ Mikhail V. Kozlov $^{2}$ (]
}

Received: 16 March 2021 / Accepted: 13 February 2022 / Published online: 24 February 2022

(c) The Author(s) 2022

\begin{abstract}
Long-term exposure to primary air pollutants, such as sulphur dioxide $\left(\mathrm{SO}_{2}\right)$ and nitrogen oxides $\left(\mathrm{NO}_{\mathrm{x}}\right)$, alters the structure and functions of forest ecosystems. Many biochemical and biogeochemical processes discriminate against the heavier isotopes in a mixture; thus, the values of $\delta^{13} \mathrm{C}$ and $\delta^{15} \mathrm{~N}$ (i.e. the ratio of stable isotopes ${ }^{13} \mathrm{C}$ to ${ }^{12} \mathrm{C}$ and that of ${ }^{15} \mathrm{~N}$ to ${ }^{14} \mathrm{~N}$, respectively) may give insights into changes in ecosystem processes and identify the immediate drivers of these changes. We studied sources of variation in the $\delta^{13} \mathrm{C}$ and $\delta^{15} \mathrm{~N}$ values in the foliage of eight boreal forest $\mathrm{C} 3$ plants at 10 sites located at the distance of 1-40 km from the Monchegorsk nickel-copper smelter in Russia. From 1939-2019, this smelter emitted over $14,000,000$ metric tons $(\mathrm{t})$ of $\mathrm{SO}_{2}, 250,000 \mathrm{t}$ of metals, primarily nickel and copper, and 140,000 $\mathrm{t}$ of $\mathrm{NO}_{\mathrm{x}}$. The $\delta^{13} \mathrm{C}$ value in evergreen plants and the $\delta^{15} \mathrm{~N}$ value in all plants increased near the smelter independently of the plant mycorrhizal type. We attribute the pollution-related increase in the foliar $\delta^{13} \mathrm{C}$ values of evergreen species mainly to direct effects of $\mathrm{SO}_{2}$ on stomatal conductance, in combination with pollution-related water stress, which jointly override the potential opposite effect of increasing ambient $\mathrm{CO}_{2}$ concentration on $\delta^{13} \mathrm{C}$ values. Stomatal uptake of $\mathrm{NO}_{\mathrm{x}}$ and root uptake of ${ }^{15} \mathrm{~N}$-enriched organic $\mathrm{N}$ compounds and $\mathrm{NH}_{4}{ }^{+}$may explain the increased foliar $\delta^{15} \mathrm{~N}$ values and elevated foliar $\mathrm{N}$ concentrations, especially in the evergreen trees (Pinus sylvestris), close to Monchegorsk, where the soil inorganic $\mathrm{N}$ supply is reduced due to the impact of long-term $\mathrm{SO}_{2}$ and heavy metal emissions on plant biomass. We conclude that, despite the uncertainties in interpreting $\delta^{13} \mathrm{C}$ and $\delta^{15} \mathrm{~N}$ responses to pollution, the Monchegorsk smelter has imposed and still imposes a great impact on $\mathrm{C}$ and $\mathrm{N}$ cycling in the surrounding N-limited subarctic forest ecosystems.
\end{abstract}

Keywords Stable isotopes $\cdot$ Sulphur dioxide $\cdot$ Heavy metals $\cdot$ Kola Peninsula $\cdot$ Leaf longevity $\cdot$ Mycorrhiza

\section{Introduction}

Decreases in the global emissions of sulphur dioxide $\left(\mathrm{SO}_{2}\right)$ and nitrogen oxides $\left(\mathrm{NO}_{\mathrm{x}}\right)$ from energy production and traffic have occurred rather slowly (Huang et al. 2017; Zhong et al. 2020), and the dry and wet depositions of sulphur (S) and nitrogen $(\mathrm{N})$ remain high over large areas (Tan et al.

Communicated by Gangrong Shi.

Mikhail V. Kozlov

mikoz@utu.fi

1 Faculty of Biological and Environmental Sciences, University of Helsinki, Viikinkaari 1, P.O. Box 65 , 00014 Helsinki, Finland

2 Department of Biology, University of Turku, 20014 Turku, Finland
2018). These observations justify the need for further studies on the effects of chronic exposure to air pollutants on ecosystem processes, on the biogeochemical cycles of carbon (C) and $\mathrm{N}$ in terrestrial ecosystems, and particularly on the plant physiology. Gaseous air pollutants, especially $\mathrm{SO}_{2}$ and ozone $\left(\mathrm{O}_{3}\right)$, modify stomatal conductance and, consequently, uptake of gaseous pollutants by plants, reduce photosynthesis, alter C allocation within plants and reduce leaf longevity (Winner and Atkinson 1986). The intimate mechanisms behind pollution-induced changes in ecosystem processes can be deciphered by studying the values of $\delta^{13} \mathrm{C}$ and $\delta^{15} \mathrm{~N}$ (i.e. the ratios of the stable isotopes ${ }^{13} \mathrm{C}$ to ${ }^{12} \mathrm{C}$ and ${ }^{15} \mathrm{~N}$ to ${ }^{14} \mathrm{~N}$, respectively) in tree foliage, rings and roots (Gebauer and Schulze 1991; Korontzi et al. 2000; Wagner and Wagner 2006; Savard 2010; Pardo et al. 2006; Savard et al. 2021).

Heavily polluted areas, which still persist in many countries, can be considered opportunistic macrocosms (or 
unique laboratories) for integrated research on the effects of air pollution on ecosystem structure and functions (Liebhold 2019). In the present study, we report the results of an ecosystem-wide, long-term, field 'experiment' conducted on the northern boreal forests. During the course of this 'experiment', large areas of pristine forests have been exposed to emissions from the nickel-copper (Ni-Cu) smelter at Monchegorsk, Russia, which started operating in 1939. For the past 80 years, the Monchegorsk smelter has emitted over $14,000,000$ metric tons ( $\mathrm{t}$ ) of $\mathrm{SO}_{2}, 250,000 \mathrm{t}$ of metals (primarily $\mathrm{Ni}, \mathrm{Cu}$ and cadmium) and $140,000 \mathrm{t}$ of $\mathrm{NO}_{\mathrm{x}}$ into the ambient air (Kozlov et al. 2009; V. Barcan, personal communication).

To date, over $250 \mathrm{~km}^{2}$ of the area around Monchegorsk, which was originally covered by coniferous forests, has been transformed into industrial barrens; the total area affected by air pollution has been estimated to exceed $10,000 \mathrm{~km}^{2}$ (Kozlov et al. 2009). Outside the industrial barrens, the emissions from the Monchegorsk smelter have decreased the aboveground plant biomass and, consequently, ecosystem $\mathrm{C}$ and $\mathrm{N}$ pools to $4 \%$ at the sites $\leq 8 \mathrm{~km}$ from the smelter vs those $>26 \mathrm{~km}$ from it (Manninen et al. 2015). The impact of $\mathrm{SO}_{2}$ and $\mathrm{NO}_{\mathrm{x}}$ emissions from the Russian smelters located in the Kola Peninsula has been detected even in the adjacent regions of Finland, up to $150 \mathrm{~km}$ from the smelter, in the form of elevated needle sulphur $(\mathrm{S})$ and $\mathrm{N}$ concentrations in Scots pine (Pinus sylvestris L.) (Manninen et al. 1997). We also found that the foliar $\mathrm{N}$ concentration increased with increasing pollution load in conifers, whereas it decreased especially in shrubs (Empetrum nigrum ssp. hermaphroditum (Hagerup) Böcher, Vaccinium myrtillus L., Vaccinium uliginosum L., Vaccinium vitis-idaea L.). By contrast, the foliar C concentration increased in Betula pubescens var. pumila (L.) Govaerts and V. uliginosum with increasing proximity to the pollution source (Manninen et al. 2015). The mechanisms that regulate these foliar $C$ and $\mathrm{N}$ concentrations in vascular plants growing under chronic exposure to a mixture of air pollutants are not well understood.

One approach for measuring changes in $\mathrm{C}$ and $\mathrm{N}$ concentrations is to use stable isotopes as many biochemical and biogeochemical processes discriminate against a heavier isotope in a mixture of isotopes. For instance, ${ }^{13} \mathrm{CO}_{2}$ is discriminated against ${ }^{12} \mathrm{CO}_{2}$ when $\mathrm{CO}_{2}$ is taken from the atmosphere and during photosynthetic $\mathrm{C}$ fixation in $\mathrm{C} 3$ plants (Farquhar et al. 1972; Dawson et al. 2002). Similarly, plant uptake and assimilation of both soil-derived ammonium $\left(\mathrm{NH}_{4}{ }^{+}\right)$and nitrate $\left(\mathrm{NO}_{3}{ }^{-}\right)$discriminate more against ${ }^{15} \mathrm{~N}$ than ${ }^{14} \mathrm{~N}$ (Garten 1993; Högberg et al. 1999), and isotopic discrimination of ${ }^{15} \mathrm{~N}$ also occurs during mineralisation of soil $\mathrm{N}$ (Garten 1993; Nadelhoffer and Fry 1988). Therefore, the ratios of stable isotopes may serve as measures of these processes (Peterson and Fry 1987; Dawson et al. 2002).
The $\delta^{13} \mathrm{C}$ values in a terrestrial plant depend on the photosynthetic pathway (C3, C4 or CAM plants) (O'Leary 1981; Rounick and Winterbourn 1986) and functional group or life form, i.e. group of plants with similar physiological characteristics such as trees, shrubs and forbs, either evergreen or deciduous (Brooks et al. 1997; Flanagan et al. 1997a; Lavergne et al. 2020). The foliar and tree-ring $\delta^{13} \mathrm{C}$ values also vary with environmental factors, and particularly water availability including vapour pressure deficit that affects stomatal functions and photosynthesis (O'Leary 1981; Dawson et al. 2002; Klein et al. 2005; Guerrieri et al. 2020). In other words, reduced water availability usually reduces stomatal conductance leading to increased $\delta^{13} \mathrm{C}$ values (Guerrieri et al. 2020; Lavergne et al. 2020; Marchand et al. 2020).

Foliar $\mathrm{C}$ is derived from atmospheric $\mathrm{CO}_{2}$ via photosynthesis, whereas foliar $\mathrm{N}$ mainly originates from the soil. Thus, the $\delta^{15} \mathrm{~N}$ values of plants in pristine areas are usually close to those in the soil (Peterson and Fry 1987), although forest plants usually have a lower $\delta^{15} \mathrm{~N}$ value than those found in the soil total-N (Garten 1993; Nadelhoffer and Fry 1994). Moreover, the foliar $\delta^{15} \mathrm{~N}$ values are more depleted in mycorrhizal than in non-mycorrhizal plants due to fractionation by the mycorrhiza (Michelsen et al. 1998; Craine et al. 2009). The $\delta^{15} \mathrm{~N}$ value of soil depends on the amount of $\mathrm{N}$ and any isotopic fractionations occurring during decomposition (i.e. mineralisation, nitrification and denitrification processes) (Högberg 1997), with each transformation being less enriched in ${ }^{15} \mathrm{~N}$ than the initial substrate: $\mathrm{NO}_{3}{ }^{-}<\mathrm{NH}_{4}{ }^{+}<$fresh litter $<$old soil organic matter (Gebauer and Dietrich 1993; Schulze et al. 1994). Michelsen et al. (1998) hypothesised that, in the northern low $\mathrm{N}$ ecosystems, the foliar $\delta^{15} \mathrm{~N}$ values are lower in ericoid and ectomycorrhizal than in non-mycorrhizal and arbuscular mycorrhizal plants because the ericoid and ectomycorrhizal plants have a higher uptake of free amino acids than $\mathrm{NH}_{4}{ }^{+}$. By contrast, ${ }^{15} \mathrm{~N}$-enriched $\mathrm{NH}_{4}{ }^{+}$may be the main $\mathrm{N}$ source of non-mycorrhizal and arbuscular mycorrhizal plants because the remaining plant-available $\mathrm{NH}_{4}{ }^{+}$in the soil may have become ${ }^{15} \mathrm{~N}$-enriched due to fractionation during microbial immobilization of $\mathrm{NH}_{4}{ }^{+}$.

Stable isotope distributions are also affected by the direction and magnitude of air pollution-driven changes. For example, the $\delta^{13} \mathrm{C}$ values depend on the pollutant composition and concentration, the duration of the exposure and the plant species (Martin et al. 1988). Multiple field studies have reported increased $\delta^{13} \mathrm{C}$ values in the tree-rings of conifers in $\mathrm{SO}_{2}$-polluted areas close to $\mathrm{Cu}$ smelters in the USA and Canada (Martin and Sutherland 1990; Savard et al. 2004, 2020) or coal power plants in Germany (Wagner and Wagner 2006). By contrast, $\mathrm{SO}_{2}$ and heavy metal emissions from a large Russian $\mathrm{Cu}$ smelter did not affect foliar $\delta^{13} \mathrm{C}$ values in either woody or herbaceous plants (Veselkin et al. 2019), while exposure to a pollutant mixture containing $\mathrm{O}_{3}$, 
in addition to $\mathrm{S}$ and $\mathrm{N}$ compounds, decreased the foliar $\delta^{13} \mathrm{C}$ values in pine (Pinus ponderosa Douglas ex C. Lawson) and oak (Quercus kelloggii Newb.) in a Californian forest ecosystem (Korontzi et al. 2000). Decreased foliar $\delta^{13} \mathrm{C}$ values in polluted areas have been attributed to anthropogenic $\mathrm{CO}_{2}$ emissions. This assumes that the effect of fixation of ${ }^{13} \mathrm{C}$-depleted $\mathrm{CO}_{2}$ produced by fossil fuel combustion is greater than the $\mathrm{C}$ discrimination effect due to increased $\mathrm{SO}_{2}, \mathrm{NO}_{\mathrm{x}}$ and/or $\mathrm{O}_{3}$ concentrations (Kwak et al. 2009). Recent studies on tree-ring $\delta^{13} \mathrm{C}$-derived intrinsic water use efficiency, which is an estimate of the leaf-level ratio between assimilation and stomatal conductance integrated across the whole canopy and the entire growing season (Medrano et al. 2015) suggest, however, that especially the responses of boreal conifers to elevated $\mathrm{CO}_{2}$ have been strongly overestimated in previous studies. This is because developmental changes (tree size, stand age), climate and differences in site conditions including atmospheric $\mathrm{S}$ and $\mathrm{N}$ pollution have not been accounted for (Guerrieri et al. 2020; Marchand et al. 2020; Savard et al. 2020).

Plants take up gaseous $\mathrm{N}$ pollutants directly from the atmosphere through their stomata and/or cuticles (Morikawa et al. 1998; Geßler et al. 2002). This N may support additional growth (Siegwolf et al. 2001) or it may be stored (Stulen et al. 1998) and/or translocated to roots to adapt $\mathrm{N}$ uptake from the soil to meet the actual $\mathrm{N}$ demand of the plant (Muller et al. 1996). Deposition of atmospheric ammonia $\left(\mathrm{NH}_{3}\right)$ and $\mathrm{NH}_{4}{ }^{+}$decreases the foliar $\delta^{15} \mathrm{~N}$ value (Pardo et al. 2006), while $\mathrm{NO}_{\mathrm{x}}$ emissions increase it (Jung et al. 1997; Ammann et al. 1999; Redling et al. 2013; Sensula 2015) relative to unpolluted sites. However, data on the impacts of pollutant mixtures on the foliar $\delta^{15} \mathrm{~N}$ values remain scarce and contradictory. For instance, Guerrieri et al. (2009) found a decrease in the $\delta^{15} \mathrm{~N}$ value of oak (Quercus cerris L.) leaves close to an oil refinery (emitting mainly $\mathrm{SO}_{2}, \mathrm{NO}_{\mathrm{x}}$ and $\mathrm{CO}_{2}$ ), but an increase in that of spruce (Picea abies (L.) Karst.) needles close to a freeway (where $\mathrm{NO}_{\mathrm{x}}$ emission was dominating) when compared with the foliar $\delta^{15} \mathrm{~N}$ values at control sites. They explained these results as representing a potential difference in $\delta^{15} \mathrm{~N}$ between the two pollution sources due to the different combustion processes and treatment of the exhaust fumes and/or to reductions in stomatal opening and, consequently, $\mathrm{NO}_{\mathrm{x}}$ uptake due to the lower water availability at the semi-arid sites close to the oil refinery. Veselkin et al. (2019), in turn, considered increased rooting depth as a possible explanation for the increased foliar $\delta^{15} \mathrm{~N}$ values observed in forest ecosystems highly polluted by $\mathrm{SO}_{2}$ and heavy metals, given that the $\delta^{15} \mathrm{~N}$ value of soil increased with increasing depth.

Predicting foliar $\delta^{15} \mathrm{~N}$ values is difficult for various reasons. The nitrogen dioxide $\left(\mathrm{NO}_{2}\right)$ concentration increases, whereas that of nitric oxide (NO) decreases, with increasing distance from the emission source, due to the oxidation of
$\mathrm{NO}$ to $\mathrm{NO}_{2}$ (Wellburn 1990; Clapp and Jenkin 2001). Moreover, the plant-available $\mathrm{NH}_{4}{ }^{+}$and $\mathrm{NO}_{3}{ }^{-}$in the humus layer in $P$. sylvestris forests decrease towards our polluter (Lukina and Nikonov 1999), whereas plant root colonisation with different mycorrhizal groups either remains unchanged or decreases with an increase in pollution (Ruotsalainen et al. 2007, 2009). The amount of plant-available $\mathrm{NH}_{4}{ }^{+}-\mathrm{N}$ in the humus layer at plots between the trees was reported to be $279 \mathrm{mg} \mathrm{kg}^{-1}$ at a distance of $\sim 60 \mathrm{~km}$ vs $33-53 \mathrm{mg} \mathrm{kg}^{-1}$ at the sites $\leq 8 \mathrm{~km}$ from the smelter. The corresponding range for the amount of plant-available $\mathrm{NO}_{3}{ }^{-} \mathrm{N}$ was from 49 to 9-13 $\mathrm{mg} \mathrm{kg}^{-1}$ (Lukina and Nikonov 1999). The total $\mathrm{N}$ content of the humus layer has varied from 0.7 to $1.8 \%$ in the area (Reimann et al. 2011), with no clear air pollutionrelated pattern. Given that both coniferous and deciduous trees preferentially utilise $\mathrm{N}$ from the humus layer, despite their different root distributions in the soil profile (Gebauer and Schulze 1991; Gebauer and Dietrich 1993), the observation that the tree foliar and the organic (humus) layer $\delta^{15} \mathrm{~N}$ values show similar site-specific variations is not surprising (Jung et al. 1997).

The proportion of the total reduced $\mathrm{N}$ in the plant foliage derived from $\mathrm{NO}_{2}$ can be over twofold in deciduous trees such as Populus species compared to coniferous species such as P. abies (Morikawa et al. 1998). The root uptake of organic $\mathrm{N}_{\text {vs }} \mathrm{NH}_{4}{ }^{+} \mathrm{vs} \mathrm{NO}_{3}{ }^{-}$by the roots may also vary with different rooting depths (Schulze et al. 1994). For example, in low $\mathrm{pH}$ soils, more $\mathrm{NH}_{4}{ }^{+}$than $\mathrm{NO}_{3}{ }^{-}$is taken up by roots in the organic layer whereas more $\mathrm{NO}_{3}{ }^{-}$is taken up in the mineral soil (Schulze 1989). $\mathrm{NH}_{4}{ }^{+}$accounts for $67-85 \%$ of the inorganic $\mathrm{N}$ fraction in the humus layer across our study area. Given the low level of plant available inorganic $\mathrm{N}$ in the soil humus layer with no change in the ratio of $\mathrm{NO}_{3}{ }^{-} \mathrm{N}$ to $\mathrm{NH}_{4}^{+}-\mathrm{N}$ towards the smelter (Lukina and Nikonov 1999), as well as the low soil pH (3.5-4.2) in the studied forest ecosystems (Manninen et al. 2015), nitrification is considered minimal, as its consequent impact on the ${ }^{15} \mathrm{~N}$ signal of the soil $\mathrm{NH}_{4}{ }^{+}$and the amount of $\mathrm{NO}_{3}{ }^{-}$in the soil (Garten 1993; Savard et al. 2021). Therefore, we consider that the mycorrhizal plants mainly take up organic $\mathrm{N}$ (free amino acids), whereas the non-mycorrhizal plants (graminoids, sedges, etc.) mainly take up ${ }^{15} \mathrm{~N}$-enriched $\mathrm{NH}_{4}{ }^{+}$. Said this, increased root uptake of $\mathrm{NO}_{3}{ }^{-}$derived from atmospheric deposition towards the polluter cannot either be excluded as $\mathrm{NO}_{\mathrm{x}}$ emissions with distinct $\delta^{15} \mathrm{~N}$ signals may directly modify the $\mathrm{NO}_{3}-\delta{ }^{15} \mathrm{~N}$ values in surface soils in boreal forests (Savard et al. 2021).

The aim of the present study was to uncover the sources of variation in foliar $\delta^{13} \mathrm{C}$ and $\delta^{15} \mathrm{~N}$ values in boreal forest $\mathrm{C} 3$ plants that have experienced a long-term exposure to $\mathrm{SO}_{2}$, $\mathrm{NO}_{x}$, heavy metal and $\mathrm{CO}_{2}$ emissions from the Monchegorsk smelter. Based on earlier studies, we expected to find (i) an increase in foliar $\delta^{13} \mathrm{C}$ values with the increasing pollution 
(i.e. proximity to the smelter) due to a decrease in stomatal conductance caused by phytotoxic air pollutants. Moreover, the higher sensitivity of conifers to $\mathrm{SO}_{2}$ and $\mathrm{NO}_{2}$ (e.g. in terms of crown condition) (Ozolincius et al. 2005) suggests that (ii) the pollution-driven change in $\delta^{13} \mathrm{C}$ values will be more pronounced in evergreen than in deciduous species. Due to the increasing $\mathrm{N}$-limitation resulting from decreasing levels of plant-available $\mathrm{NH}_{4}{ }^{+}$and $\mathrm{NO}_{3}{ }^{-}$in the humus layer, we hypothesised that (iii) foliar $\delta^{15} \mathrm{~N}$ values increase with increase in ambient air $\mathrm{NO}_{\mathrm{x}}$ close to the smelter due to stomatal uptake of ${ }^{15} \mathrm{~N}$-enriched $\mathrm{NO}_{\mathrm{x}}$ derived from fossil fuels (Xu et al. 2019; and references therein). We also hypothesised that (iv) the rate of change in $\delta^{15} \mathrm{~N}$ along the pollution gradient differs among plant species due to species-specific stomatal uptake and assimilation of $\mathrm{NO}_{2}$ (Morikawa et al. 1998). Finally, we measured foliar $\mathrm{N}$ concentrations as we hypothesised that (v) they describe the combined effects of dry- and wet-deposited $\mathrm{N}$ and soil $\mathrm{N}$ availability (i.e. the increased stomatal uptake of $\mathrm{NO}_{\mathrm{x}}$ compensating for the decreasing root supply of $\mathrm{N}$ with increasing proximity to the smelter).

\section{Materials and methods}

\section{Study area}

The Monchegorsk smelter is located within the Polar Circle, close to the northern limit of boreal coniferous forests formed by Scots pine (P. sylvestris) and Norway spruce ( $P$. abies). The mean temperature at Monchegorsk is $-13.8^{\circ} \mathrm{C}$ in January and $14.1{ }^{\circ} \mathrm{C}$ in July, and the mean annual precipitation is $561 \mathrm{~mm}$. The frost-free period ranges from 50 to 100 days. The peak values of annual emissions amounted to 278,000 tonnes (t) of $\mathrm{SO}_{2}$ in $1983,5100 \mathrm{t}$ of $\mathrm{NO}_{\mathrm{x}}$ in 1986-1993 and 13,150 t of non-ferrous metals in 1987 (Kozlov et al. 2009; Manninen et al. 2015). The annual emissions in 2019 were close to $40,000 \mathrm{t}$ of $\mathrm{SO}_{2}, 700 \mathrm{t}$ of $\mathrm{NO}_{\mathrm{x}}$ and $800 \mathrm{t}$ of metals (264 t of Ni, 513 of $\mathrm{Cu}$ and $10 \mathrm{t}$ of cobalt) in 2019 (V. Barcan, pers. comm.). The combined annual $\mathrm{CO}_{2}$ emissions of the smelter and its boiler houses are estimated at 374,000 $\mathrm{t}$ and arise from combustion of fuel oil (personal communication by an anonymous representative of Norilsk Nikel). The smelter is located ca. $2 \mathrm{~km}$ from the centre of Monchegorsk. In 1989-1999, the smelter produced $99.6-99.9 \%$ of all reported atmospheric emissions from the town of Monchegorsk (Kozlov et al. 2009).

Air quality data for our study area are scarce and are mostly limited to measurements conducted at Monchegorsk. The modelled average $\mathrm{SO}_{2}$ concentration was $>60 \mu \mathrm{g} \mathrm{m}^{-3}$ between July 1990 and June 1991 in the most polluted area (Anttila et al. 1995), while average concentrations of $30 \mu \mathrm{g}$ $\mathrm{SO}_{2} \mathrm{~m}^{-3}, 20 \mu \mathrm{gO}_{2} \mathrm{~m}^{-3}$ and $<10 \mu \mathrm{g} \mathrm{NO} \mathrm{m}{ }^{-3}$ were reported for the period 1993-1997 in Monchegorsk (Makarova and Rigina 1999). The $\mathrm{SO}_{2}$ and $\mathrm{NO}_{\mathrm{x}}$ emissions have been reduced further since 1993, so an annual mean $\mathrm{SO}_{2}$ concentration of $15 \mu \mathrm{g} \mathrm{m}^{-3}$ was reported for Monchegorsk in 2019. However, high 1-h SO${ }_{2}$ concentrations of up to $225 \mu \mathrm{g} \mathrm{m}^{-3}$ continue to occur (Ministry of Natural Resources and Ecology in the Murmansk Oblast 2020). In comparison, the annual mean $\mathrm{SO}_{2}$ and $\mathrm{NO}_{2}$ concentrations in Sammaltunturi, Finnish Lapland, which can serve a reference area in terms of air quality, were $0.7 \mu \mathrm{g} \mathrm{m}^{-3}$ and $0.9 \mu \mathrm{g} \mathrm{m}^{-3}$, respectively, in 2019 (https://www.ilmatieteenlaitos.fi/ilmansaasteet\#tilas to).

Long-term deposition of atmospheric pollutants, especially $\mathrm{SO}_{2}$ and heavy metals, has transformed the previously forested areas in the vicinity of the smelter into industrial barrens-bleak open landscapes with small patches of vegetation surrounded by bare land. In these habitats, conifers are practically absent, and low-stature $(0.2-3 \mathrm{~m}$ tall) mature mountain birches (B. pubescens var. pumila), growing 5-15 $\mathrm{m}$ apart, dominate the vegetation. In the more moderately polluted area, the top canopy is formed by Norway spruce that shows visible signs of damage (dead upper parts of crowns, low needle longevity) and by undamaged mountain birches, while field-layer and ground-layer vegetation is sparse. In visibly unaffected Norway spruce forests, mountain birches are also common, and E. nigrum ssp. hermaphroditum, V. myrtillus and V. vitis-idaea dominate in the dense field layer (Kozlov et al. 2009; Manninen et al. 2015).

\section{Study sites, study plants and leaf sampling}

The samples of eight plant species (Table 1) were collected from 18-22 August 2019 at 10 sites located $1-40 \mathrm{~km}$ from the smelter (Online Resource: Table S1, Fig. S1). The sites were selected for a large-scale Finnish-Russian project using the protocol described by Vorobeichik and Kozlov (2012). At the first stage, representative study sites were selected (Table 1); these, to the best of our knowledge, had similar vegetation and soil during the pre-industrial period. Some trees may have been logged from the sites more than 50 years ago, but none of our sites has been affected by logging or fire for the last 40 years. At the second stage, 12 sampling plots $25 \times 25 \mathrm{~m}$ in size were marked at each site and two of these plots were randomly selected for the study. We attempted to collect foliage of plants with different functional traits and colonised by different types of mycorrhiza (Table 1), but we were constrained by the overall composition of the flora of our study region and by the absence of several plant species in the heavily polluted (barren) sites. All our plant species had C3 type of photosynthesis.

Plants were collected on a first-found, first-sampled basis. Within a site, the two plants of the same species were sampled at least $25 \mathrm{~m}$ apart. All the sampled plants were 
Table 1 Characteristics of studied species

\begin{tabular}{llllll}
\hline Species & Family & Life form & Leaf longevity & Mycorrhiza $^{\mathrm{a}}$ & Sample size $^{\mathrm{b}}$ \\
\hline Betula pubescens & Betulaceae & Tree & Deciduous & ECM & $10(20)$ \\
Carex sp. & Cyperaceae & Grass & Deciduous & NM & $9(18)$ \\
Deschampsia flexuosa & Graminaceae & Grass & Deciduous & AM & $10(20)$ \\
Empetrum nigrum & Ericaceae & Dwarf shrub & Evergreen & ERM & $10(20)$ \\
Orthilia secunda & Ericaceae & Dwarf shrub & Evergreen & AM & $10(17)$ \\
Pinus sylvestris & Pinaceae & Tree & Evergreen & ECM & $10(20)$ \\
Rubus chamaemorus & Rosaceae & Forb & Deciduous & NM & $8(16)$ \\
Vaccinium myrtillus & Ericaceae & Dwarf shrub & Deciduous & ERM & $10(20)$ \\
\hline
\end{tabular}

${ }^{a} N M$, non-mycorrhizal; $A M$, arbuscular mycorrhiza; $E C M$, ectomycorrhiza; $E R M$, ericoid mycorrhiza

${ }^{\mathrm{b}}$ Number of sampled sites; in parentheses—number of sampled individuals mature, i.e. had generative organs; the sampled trees aged, on average, $40-60$ years. The aboveground parts of small (herbaceous) plant individuals were collected as a whole, whereas several branches were collected from trees and dwarf shrubs. Plants or their branches were placed in plastic bags and transported to the laboratory, where current-year leaves were detached, cleaned of soil and debris and placed into paper bags. The dry weights of individual samples varied from 0.5 to $2.0 \mathrm{~g}$.

\section{Analytical procedure}

The leaves were oven-dried at $50{ }^{\circ} \mathrm{C}$ for $4-5$ days, ground to a powder using a ball mill (Retsch MM200, Retsch GmbH, Haan, Germany) and then wrapped in tin ( $\mathrm{Sn}$ ) foil capsules $(1000 \mu \mathrm{g})$. The isotopic composition was determined using a Thermo-Finnigan Delta V Plus continuous-flow IRMS (Thermo Electron GmbH, Bremen, Germany) coupled to an elemental analyser (Thermo Flash 1112, Thermo Electron); this equipment was located at the 'Instrumental methods in ecology' Joint Usage Center of the A.N. Severtsov Institute of Ecology and Evolution, Moscow, Russia. The isotope composition of $\mathrm{C}$ and $\mathrm{N}$ was expressed in the $\delta$-notation relative to the international standard (atmospheric nitrogen and V-PDB, respectively $): \delta \mathrm{X}(\% \circ)=\left[\left(R_{\text {sample }} / R_{\text {standard }}\right)-1\right]$ $\times 1000$, where $\mathrm{R}$ is the ratio of the heavier isotope to the lighter isotope. Samples were analysed with a reference gas calibrated against IAEA (Vienna, Austria) reference materials USGS $40\left(\delta^{13} \mathrm{C}=-26.4 \% ; ; \delta^{15} \mathrm{~N}=-4.5 \% 0\right)$ and USGS $41\left(\delta^{13} \mathrm{C}=37.6 \% \circ ; \delta^{15} \mathrm{~N}=47.6 \% \circ\right)$. The drift was corrected using an internal laboratory standard (casein, Elemental Microanalysis Ltd.; $\delta^{13} \mathrm{C}=-26.98 \% o, \delta^{15} \mathrm{~N}=5.94 \%$ ). The standard deviation of $\delta^{13} \mathrm{C}$ and $\delta^{15} \mathrm{~N}$ values in reference material $(n=8)$ was $<0.15 \%$.

\section{Data analysis}

Both $\delta^{13} \mathrm{C}$ and $\delta^{15} \mathrm{~N}$ values were analysed with a linear mixed model (SAS GLIMMIX procedure; SAS Institute,
2009). In the first model, we considered plant species as a fixed effect and the ln-transformed distance from the smelter, which strongly and negatively correlates with pollution load (Kozlov et al. 2009; Manninen et al. 2015), as a covariate. The site of plant origin was treated as a random intercept effect. The unbalanced sampling design (i.e. the absence of an evergreen non-mycorrhizal species) (Table 1) did not allow us to include both mycorrhizal type and leaf longevity in the same statistical model. Therefore, the second model explored the differences between evergreen and deciduous species, while the third model addressed variation among plants with different mycorrhizal statuses. For the analysis of $\mathrm{N}$ concentrations, we only used the first model.

We facilitated accurate $F$ tests of the fixed effects by adjusting the standard errors and denominator degrees of freedom by the latest version of the method described by Kenward and Roger (2009). The significance of a random factor was evaluated by calculating the likelihood ratio and testing it against the chi-squared distribution (Littell et al. 2006). The relationships between variables were explored by calculating the Pearson product-moment correlation coefficients.

\section{Results}

\section{Foliar $\delta^{13} \mathrm{C}$ and $\delta^{15} \mathrm{~N}$ values}

Both $\delta^{13} \mathrm{C}$ and $\delta^{15} \mathrm{~N}$ values (Online Resource: Data $\mathrm{S} 1$ ) varied among plant species (Fig. 1) and tended to increase towards the polluter. The rates of these increases were similar across the studied species (Model 1 in Table 2). The range of both $\delta^{13} \mathrm{C}$ and $\delta^{15} \mathrm{~N}$ values across the sites was widest in Orthilia secunda (L.) House (mean \pm SD: $-28.7 \pm 2.2 \%$ and $4.86 \pm 2.91 \%$, respectively) and narrowest in $V$. myrtillus $(-32.4 \pm 0.6 \%$ ond $-1.35 \pm 1.28 \%$, respectively).

The $\delta^{15} \mathrm{~N}$ values did not differ between deciduous and evergreen plants due to the large within-group variations (Fig. 1; Model 2 in Table 2). The $\delta^{13} \mathrm{C}$ values did not change 

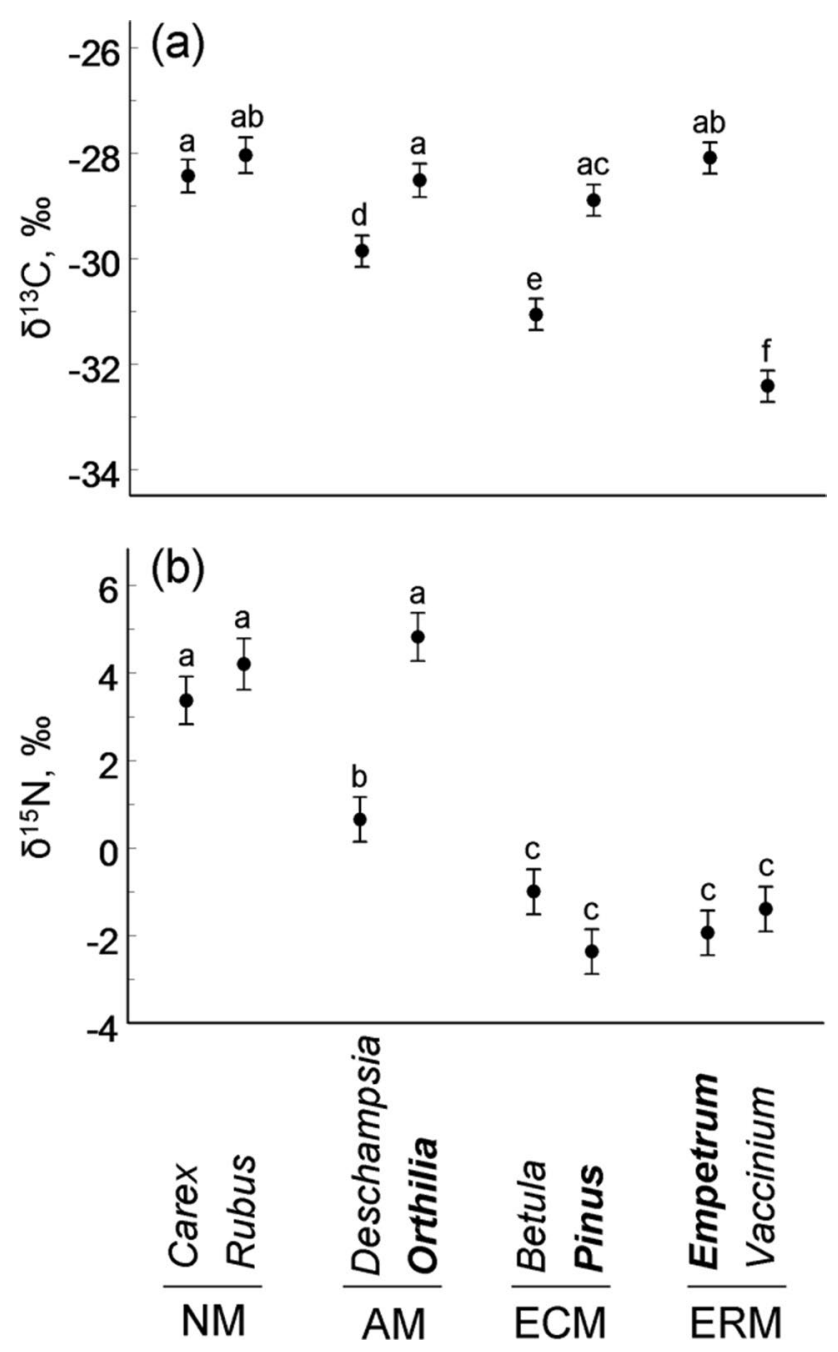

Fig. 1 Variation in foliar $\delta^{13} \mathrm{C}(\mathbf{a})$ and $\delta^{15} \mathrm{~N}$ (b) values among evergreen (boldfaced) and deciduous (other) plant species with different types of mycorrhiza (NM, non-mycorrhizal; AM, arbuscular mycorrhiza; ECM, ectomycorrhiza; ERM, ericoid mycorrhiza). The estimated marginal means $( \pm \mathrm{SE})$ are based on data collected from eight to ten study sites (consult Table 1). Values labelled with different letters indicate significant $(P<0.05)$ differences between plant species $(t$ test from SAS GLIMMIX procedure)

along the pollution gradient in deciduous species (Fig. 2a) but increased in evergreen species with increasing proximity to the smelter (Fig. 2b), especially in P. sylvestris $(r=-0.69$, $n=10$ sites, $p=0.03)$ and E. nigrum $(r=-0.71, n=10$, $p=0.02$ ).

The long-term exposure to $\mathrm{SO}_{2}, \mathrm{NO}_{\mathrm{x}}$, heavy metals and $\mathrm{CO}_{2}$ did not change the ranking of plant functional types by foliar $\delta^{13} \mathrm{C}$ values relative to unpolluted areas: the average value of $\delta^{13} \mathrm{C}$ decreased in mycorrhizal plants in the following order: evergreen shrub $=$ evergreen forb $=$ evergreen tree $>$ deciduous grass $>$ deciduous tree $>$ deciduous shrub (Fig. 1a). The $\delta^{13} \mathrm{C}$ values were as high in non-mycorrhizal plants as in evergreen mycorrhizal species.
Foliar $\delta^{15} \mathrm{~N}$ values varied with plant mycorrhizal status and among the different plant species. The highest values of $\delta^{15} \mathrm{~N}$ were found in non-mycorrhizal plants, whereas trees and shrubs with ectomycorrhiza and ericoid mycorrhiza had the lowest $\delta^{15} \mathrm{~N}$ values (Fig. 1b). Changes in both $\delta^{15} \mathrm{~N}$ and $\delta^{13} \mathrm{C}$ with distance from the polluter did not depend on plant mycorrhizal status (Model 3 in Table 2), and a slight increase in $\delta^{15} \mathrm{~N}$ towards the smelter (Fig. 2c) emerged exclusively due to the difference of the proximate site from all other sites. At the species level, the increases in $\delta^{15} \mathrm{~N}$ values towards the smelter were significant in $V$. myrtillus ( $r=-0.79, n=10$ sites, $p=0.007)$ and approached significance in Carex sp. $(r=-0.65, n=9, p=0.058)$.

\section{Foliar $\mathbf{N}$ concentrations}

The foliar $\mathrm{N}$ concentration varied among plant species $\left(F_{7,128}=3.94, p=0.0006\right)$. The variation among study sites $\left(\chi^{2}=8.96, p=0.0014\right)$ was not explained by the distance from the smelter: plant species showed individualistic changes in foliar $\mathrm{N}$ concentration, from negative to positive, along the pollution gradient (interaction term: $\left.F_{7,127.9}=2.21, p=0.04\right)$. At the species level, the increases in $\mathrm{N}$ values towards the smelter approached significance in D. flexuosa $(r=-0.62, n=10, p=0.056)$ and P. sylvestris ( $r=-0.54, n=10, p=0.1$ ), while the $\mathrm{N}$ value decreased in E. nigrum $(r=0.74, n=10, p=0.015)$ towards the smelter.

\section{Correlations among variables}

The foliar $\delta^{13} \mathrm{C}$ and $\delta^{15} \mathrm{~N}$ values positively correlated to each other $(r=0.25, n=151$ samples, $p=0.0017)$. Foliar $\delta^{15} \mathrm{~N}$ values positively correlated with $\mathrm{N}$ concentrations when tested across all the samples ( $r=0.26, n=151, p=0.0012)$. However, the latter correlation varied among species, being significant only in P. sylvestris ( $r=0.70, n=20$ samples, $p=0.0006)$ and B. pubescens $(r=0.44, n=20, p=0.05)$.

\section{Discussion}

\section{Sources of variation in $\delta^{13} \mathrm{C}$ values}

\section{Plant functional types and species}

We attribute the higher foliar $\delta^{13} \mathrm{C}$ values in evergreen than in deciduous species discovered in this study to the fundamental difference between these two functional groups of plants in the ratio of photosynthetic capacity to stomatal conductance, which can be expressed as a ratio of intracellular to ambient $\mathrm{CO}_{2}\left(c_{\mathrm{i}} / c_{\mathrm{a}}\right)$ (Farquhar et al. 1989). The average values of foliar $\delta^{13} \mathrm{C}$ in our plants followed the pattern 
Table 2 Sources of variation in the abundances of $\delta^{13} \mathrm{C}$ and $\delta^{15} \mathrm{~N}$ in plant foliage (SAS GLIMMIX procedure, type 3 tests)

\begin{tabular}{|c|c|c|c|c|c|c|}
\hline \multirow[t]{2}{*}{ Model } & \multirow[t]{2}{*}{ Effect } & \multirow[t]{2}{*}{ Source of variation } & \multicolumn{2}{|l|}{$\delta^{13} \mathrm{C}$} & \multicolumn{2}{|l|}{$\delta^{15} \mathrm{~N}$} \\
\hline & & & Statistics & $P$ value & Statistics & $P$ value \\
\hline \multirow[t]{4}{*}{1} & \multirow[t]{3}{*}{ Fixed } & Plant species & $F_{7,128.2}=9.51$ & $<0.0001$ & $F_{7,129.5}=5.85$ & $<0.0001$ \\
\hline & & Distance to polluter* & $F_{1,8.48}=5.05$ & 0.053 & $F_{1,9.97}=4.85$ & 0.052 \\
\hline & & Plant species $\times$ Distance & $F_{7,127.9}=1.71$ & 0.11 & $F_{7,129.2}=0.55$ & 0.80 \\
\hline & Random & Site & $\chi_{1}^{2}=3.07$ & 0.04 & $\chi_{1}^{2}=0.90$ & 0.17 \\
\hline \multirow[t]{5}{*}{2} & \multirow[t]{4}{*}{ Fixed } & Leaf longevity & $F_{1,133.5}=26.6$ & $<0.0001$ & $F_{1,134.5}=1.21$ & 0.27 \\
\hline & & Plant species (Leaf longevity) & $F_{6,133.2}=27.7$ & $<0.0001$ & $F_{6,134.3}=35.7$ & $<0.0001$ \\
\hline & & Distance to polluter* & $F_{1,8.06}=7.23$ & 0.03 & $F_{1,9.20}=5.58$ & 0.04 \\
\hline & & Leaf longevity $\times$ Distance & $F_{1,133.2}=6.13$ & 0.01 & $F_{1,134.2}=0.00$ & 0.77 \\
\hline & Random & Site & $\chi_{1}^{2}=3.03$ & 0.04 & $\chi_{1}^{2}=0.96$ & 0.16 \\
\hline \multirow[t]{5}{*}{3} & \multirow[t]{4}{*}{ Fixed } & Mycorrhizal type & $F_{3,131.6}=2.38$ & 0.07 & $F_{3,132.7}=9.08$ & $<0.0001$ \\
\hline & & Plant species (Mycorrhizal type) & $F_{4,131.4}=41.6$ & $<0.0001$ & $F_{4,132.5}=9.55$ & $<0.0001$ \\
\hline & & Distance to polluter* & $F_{1,7.97}=5.81$ & 0.04 & $F_{1,9.04}=5.79$ & 0.04 \\
\hline & & Mycorrhizal type $\times$ Distance & $F_{3,131.4}=0.93$ & 0.43 & $F_{3,132.4}=0.28$ & 0.84 \\
\hline & Random & Site & $\chi_{1}^{2}=2.59$ & 0.05 & $\chi_{1}^{2}=0.93$ & 0.17 \\
\hline
\end{tabular}

*Distance values were $\ln$-transformed observed in mycorrhizal C3 plants in unpolluted boreal forests (Brooks et al. 1997; Flanagan et al. 1997a).

\section{Industrial pollution}

Our first hypothesis was shown to be true for the evergreens, especially $P$. sylvestris and $E$. nigrum: foliar $\delta^{13} \mathrm{C}$ values increased with the increasing proximity to the smelter. A decrease in the foliar $\delta^{13} \mathrm{C}$ value under high air pollution usually means either decreased photosynthetic rates or assimilation of a more depleted $\mathrm{CO}_{2}$ source (Korontzi et al. 2000). The $\mathrm{c}_{\mathrm{i}} / \mathrm{c}_{\mathrm{a}}$ and $\mathrm{c}_{\mathrm{i}}$ values, calculated from the foliar $\delta^{13} \mathrm{C}$ values (as described by Betson et al. 2007), decreased towards the smelter, indicating a reduced $\mathrm{CO}_{2}$ flux into leaves and needles as a primary cause for the increased foliar $\delta^{13} \mathrm{C}$ values, rather than a reduction in photosynthesis. Increases in the $\delta^{13} \mathrm{C}$ values in both conifer needles and wood in response to exposure to $\mathrm{SO}_{2}$, either alone or in combination with $\mathrm{NO}_{2}$ and $\mathrm{O}_{3}$, have been attributed to a partial closure of stomata, which restricts $\mathrm{CO}_{2}$ entry into leaves and, consequently, impairs photosynthesis (Martin et al. 1988; Martin and Sutherland 1990; Siegwolf et al. 2001; Cada et al. 2016; Savard et al. 2020). Secondary fractionation caused by the phytotoxicity of $\mathrm{SO}_{2}$ (i.e. an increase in dark respiration and changes in photosynthate allocation and partitioning) (Wagner and Wagner 2006), including a greater production of storage carbohydrates (Agrawal and Deepak 2003), may also have contributed to the increase in foliar $\delta^{13} \mathrm{C}$ values.

Carbon isotope discrimination is a sensitive indicator of plant physiological responses to $\mathrm{SO}_{2}$ (Savard 2010; Savard et al. 2020). Our second hypothesis was also supported, i.e. the evergreen species showed a greater pollutiondriven increase than was detected in the deciduous species with increasing proximity to the smelter. However, differences were noted even between the evergreen species in terms of the rate of change in the foliar $\delta^{13} \mathrm{C}$ values along the pollution gradient. Specifically, the absence of a correlation between the foliar $\delta^{13} \mathrm{C}$ value in $O$. secunda and the proximity to the smelter may be explained by the life habit of this species, as it parasitises its mycorrhizal fungi and obtains as much as half of the $\mathrm{C}$ it needs from these fungi (Whitfield 2007).

The absolute $\delta^{13} \mathrm{C}$ values in $P$. sylvestris in Monchegorsk were similar to those reported from polluted areas in Poland (Sensula 2015) and the South Urals in Russia (Veselkin et al. 2019). In contrast to the pattern observed in Poland (Sensula 2015), our results do not suggest a significant reduction in foliar $\delta^{13} \mathrm{C}$ values due to anthropogenic $\mathrm{CO}_{2}$ emissions. The foliar $\delta^{13} \mathrm{C}$ values in $\mathrm{C} 3$ plants decrease with increasing ambient $\mathrm{CO}_{2}$ concentration because the plants try to take advantage of the increased $\mathrm{CO}_{2}$ availability to enhance their water-use efficiency, i.e. they increase the ratio of net photosynthesis to transpiration by closing their stomata. This reduction in stomatal conductance, however, does not limit photosynthesis but instead results in an increase in the ratio of leaf assimilation to stomatal conductance and, consequently, in more negative foliar $\delta^{13} \mathrm{C}$ values (Polley et al. 1993). In our study area, $\mathrm{SO}_{2}$ emissions are apparently still so high that the modest $\mathrm{CO}_{2}$ emissions from the smelter (and the apparent lack of a $\mathrm{CO}_{2}$ concentration gradient) do not compensate for the direct and indirect impacts of $\mathrm{SO}_{2}$ on foliar $\delta^{13} \mathrm{C}$ values. The recent results of Savard et al. (2020) on the impact of $\mathrm{SO}_{2}$ and $\mathrm{NO}_{\mathrm{x}}$ emissions on tree-ring $\delta^{13} \mathrm{C}$ values in boreal conifer forests in Canada support our deduction. 

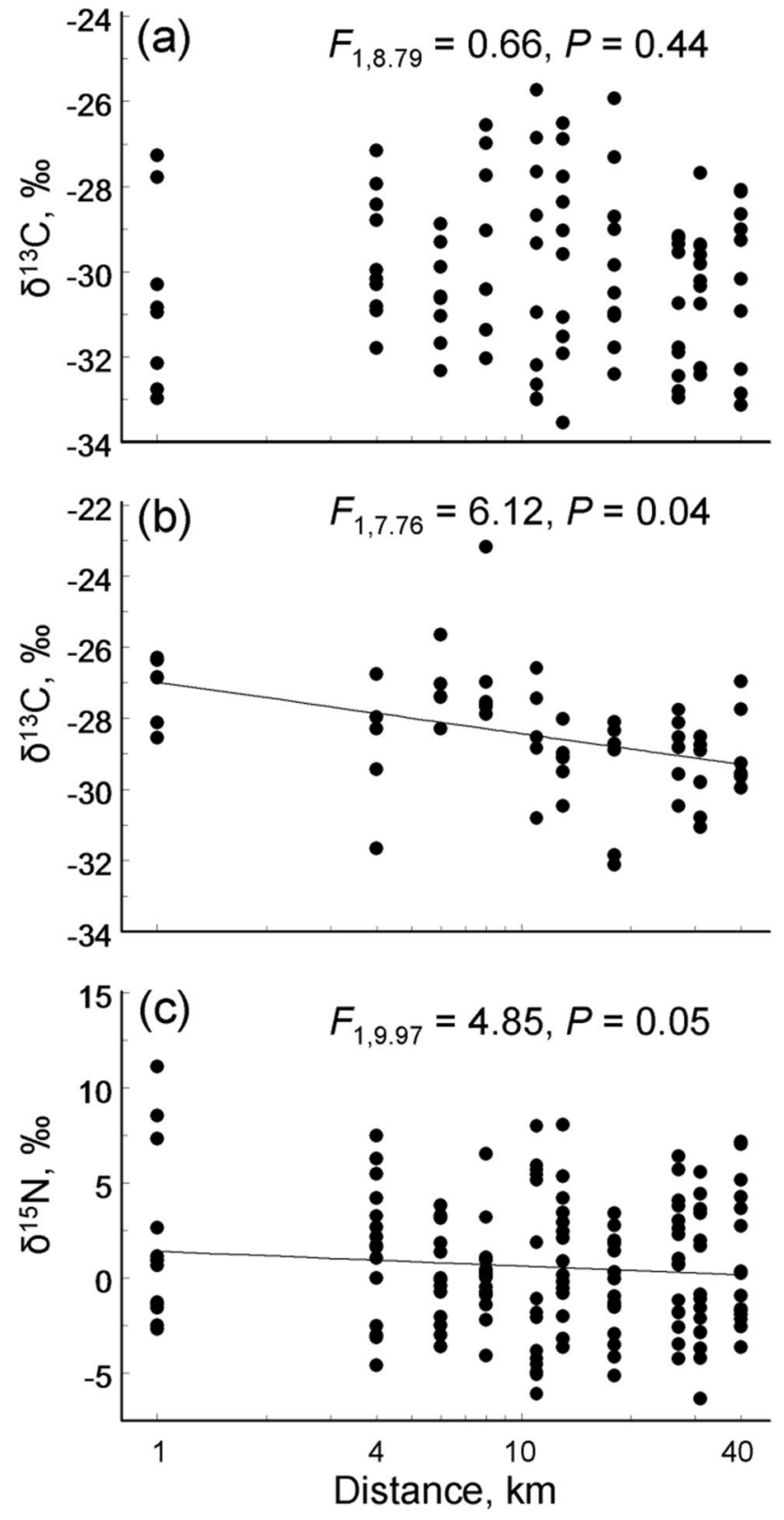

Fig. 2 Change in foliar $\delta^{13} \mathrm{C}$ values in deciduous (a) and evergreen (b) species, and in foliar $\delta^{15} \mathrm{~N}$ values in all plant species (c) along the Monchegorsk pollution gradient. Statistical analyses (consult Table 1) were based on ln-transformed values of the distance to the smelter; $F$ and $P$ values refer to the significances of the slopes

\section{Other environmental factors}

The foliar $\delta^{13} \mathrm{C}$ value not only reflects photosynthetic activity throughout the whole lifespan of the leaf tissues (Dawson et al. 2002), but it also yields information about water fluxes (Brooks et al. 1997). Higher foliar $\delta^{13} \mathrm{C}$ values have been reported in both conifers (Flanagan et al. 1997a; Choi et al. 2005; Klein et al. 2005; Wagner and Wagner 2006) and deciduous trees (Flanagan et al. 1997a; Cocozza et al. 2020) experiencing water deficit than in well-watered plants due to reductions in stomatal conductance and $\mathrm{c}_{\mathrm{i}} \mathrm{c}_{\mathrm{a}}$ (Guerrieri et al. 2009). The availability of water near the smelter is reduced due to the lower amounts of water stored in snow by the end of winter in the industrial barrens and in the heavily polluted forests vs the unpolluted forests (Kozlov 2001) combined with the higher air temperatures in warm days during the growing season (Kozlov and Haukioja 1997) and the higher wind speeds (Kozlov 2002) which increase evaporation. In addition, the $P$. sylvestris growing up to $30-50 \mathrm{~km}$ west from the smelter have stunted roots (Derome et al. 1995), which reduces their water uptake capacity despite the potentially more abundant groundwater supplies (Flanagan et al. 1997b). We therefore suggest that the increase in foliar $\delta^{13} \mathrm{C}$ values close to the smelter may be partly attributed to a pollution-induced water stress, even though this could reduce the fluxes of gaseous pollutants into the needles and leaves. Thus, although the influence of severe air pollution on $\mathrm{C}$ isotope discrimination likely overrides the effects of environmental factors such as temperature, precipitation and cloud cover (Čada et al. 2016), we cannot attribute the changes in $\delta^{13} \mathrm{C}$ solely to a direct impact of gaseous air pollutants.

\section{Sources of variation in $\delta^{15} \mathrm{~N}$ values and in $\mathrm{N}$ concentrations}

\section{Plant functional types, species and mycorrhizal status}

The average foliar $\mathrm{N}$ concentration was greater in deciduous species than in evergreen species, indicating a higher photosynthetic capacity and a larger specific leaf area in deciduous vs evergreen species (Reich et al. 1997). The lack of any difference in the foliar $\delta^{15} \mathrm{~N}$ values between the ectomycorrhizal trees and the ericoid mycorrhizal shrubs, including both evergreen and deciduous species, suggests that B. pubescens, E. nigrum, $P$. sylvestris and $V$. myrtillus used the same inorganic $\left(\mathrm{NH}_{4}{ }^{+}\right)$and organic $\mathrm{N}$ pools in the humus layer and/or that the stomatal uptake of $\mathrm{NO}_{\mathrm{x}}$ masked the potential differences in root $\mathrm{N}$ uptake. The high positive foliar $\delta^{15} \mathrm{~N}$ values in $O$. secunda $(+4.86 \%$ ), Carex sp. $(+3.40 \%$ ) and Rubus chamaemorus L. $(+4.00 \%$ ) probably indicate uptake of ${ }^{15} \mathrm{~N}$-enriched $\mathrm{N}$ from the soil. Non-mycorrhizal species such as Carex spp., as well as the mycorrhizal species typical of the northernmost ecosystems, have shown preferences for direct root uptake of free amino acids (Kielland 1994; Schimel and Chapin 1996). In our study area, this may also mean root uptake of ${ }^{15} \mathrm{~N}$-enriched free amino acids originating from plant litter.

\section{Industrial pollution}

Our third and fourth hypotheses were also confirmed, although the increase in the foliar $\delta^{15} \mathrm{~N}$ value towards the 
smelter was only significant at the species level in the deciduous $V$. myrtillus. This species had the highest calculated $\mathrm{c}_{\mathrm{i}} /$ $\mathrm{c}_{\mathrm{a}}$ and $\mathrm{c}_{\mathrm{i}}$ among our study plants $(0.77$ and $297 \mathrm{ppm}$, respectively), suggesting that it had the largest stomatal influx of atmospheric gases and the highest photosynthetic rate. Given the decreases in the plant-available $\mathrm{NH}_{4}{ }^{+}$and $\mathrm{NO}_{3}{ }^{-}$in the humus layer close to the Monchegorsk smelter (Lukina and Nikonov 1999), we attribute the overall increase in the foliar $\delta{ }^{15} \mathrm{~N}$ value across the plant species with increasing proximity to this smelter mainly to a stomatal uptake of $\mathrm{NO}_{2}$, that probably has a positive ${ }^{15} \mathrm{~N}$ signal. This is because atmospheric $\mathrm{NO}_{2}$ taken up via stomata is incorporated into free amino acids (Xu and Xiao 2017) as is the wet-deposited $\mathrm{N}$ (Nordin et al. 1998). Increase in the concentrations of $\mathrm{NO}_{2}$-derived foliar free amino acids with increased $\delta^{15} \mathrm{~N}$ value results in increased foliar and plant $\delta^{15} \mathrm{~N}$ values (Xu and Xiao 2017; Zhu et al. 2018). Moreover, Zhu et al. (2018) concluded that the $\delta^{15} \mathrm{~N}$ value of free amino acids is about the same as the $\delta^{15} \mathrm{~N}$ value of the source of atmospheric $\mathrm{N}$. Overall, the stomatal uptake can be rather high, contributing $10-25 \%$ of the total $\mathrm{N}$ budget of $P$. abies seedlings (Muller et al. 1996; Ammann et al. 1999) and 14-18\% of the total N budget of Populus $\times$ canadensis Moench cuttings (Siegwolf et al. 2001).

Both V. myrtillus and Carex spp., which showed the greatest increases in the foliar $\delta^{15} \mathrm{~N}$ value near the smelter, are clonal rhizomatous species, so they may exploit a very large soil volume for root uptake of $\mathrm{N}$ (Brooker et al. 1999). Uptake of ${ }^{15} \mathrm{~N}$-enriched (organic) $\mathrm{N}$ from the soil (Savard 2010; and references therein) could therefore partly explain the increases in the foliar $\delta^{15} \mathrm{~N}$ values towards the smelter in these species. Long-term high $\mathrm{NO}_{\mathrm{x}}$ deposition may lead to changes in the $\delta^{15} \mathrm{~N}$ value of the soil surface horizon due to the change in the $\delta^{15} \mathrm{~N}$ value of litter (Gebauer and Schulze 1991; Högberg 1997). The incorporation of water-dissolved $\mathrm{NO}_{3}{ }^{-}$by tree canopies and leaves of other species to support plant $\mathrm{N}$ nutrition can also contribute to this pattern, especially in acidic N-limited ecosystems (Bourgeois et al. 2019; Pornon et al. 2019; Salemaa et al. 2020).

We have no data on the organic $\mathrm{N}$ in the soil around Monchegorsk. However, given the reduction in the aboveground plant biomass and, consequently, the $\mathrm{N}$ pool (Manninen et al. 2015), we deduce a decrease in soil organic $\mathrm{N}$ towards the smelter. Moreover, the decrease in both the $\mathrm{NH}_{4}{ }^{+}-\mathrm{N}$ and $\mathrm{NO}_{3}{ }^{-} \mathrm{N}$ content of $P$. abies litter with increasing proximity to the smelter (Lukina and Nikonov 1999) may indicate an enhanced translocation of $\mathrm{N}$, including ${ }^{15} \mathrm{~N}$-enriched free amino acids, from senescing foliage in response to the decreasing soil $\mathrm{N}$ supply. This could be a strategy to support the $\mathrm{N}$ economy of the remaining and new foliage especially in evergreen species.

In the present study, we only observed an increasing trend $(p \leq 0.1)$ in the needle $\mathrm{N}$ concentrations of P. sylvestris towards the smelter, while a significant increase was found in P. sylvestris and Picea abies needles in an earlier study (Manninen et al. 2015). The average $\mathrm{N}$ concentration in $P$. sylvestris needles was similar to that in trees surrounding an oil refinery in southern Finland (Manninen and Huttunen 2000) and higher than in unpolluted Finnish Lapland (Manninen et al. 1997). Although the foliar $\mathrm{N}$ also includes $\mathrm{N}$ compounds that are dry- and wet-deposited on leaf surfaces, the contribution of this deposited $\mathrm{N}$ to the total $\mathrm{N}$ in foliage is much smaller than that from soil-derived $\mathrm{N}$ and stomatal uptake of $\mathrm{NO}_{\mathrm{x}}$ close to the smelter (Wellburn 1990; and references therein). A significant positive correlation between the foliar $\delta^{15} \mathrm{~N}$ value and $\mathrm{N}$ concentration across all the species, and especially in $P$. sylvestris and B. pubescens, further supports our hypothesis of an appreciable contribution of $\mathrm{NO}_{\mathrm{x}}$ to the foliar chemistry. Similarly, Roth et al. (2021) recently showed that foliar $\mathrm{N}$ concentration in conifers $(P$. abies, Abies alba Mill.), V. myrtillus and Luzula luzuloides (Lam.) Dandy \& Wilmott in Germany was positively and more strongly correlated with the deposition of oxidised $\mathrm{N}$ forms $\left(\mathrm{NO}_{\mathrm{y}}\right)$ than with the reduced $\mathrm{N}$ forms $\left(\mathrm{NH}_{\mathrm{x}}\right)$ in forest ecosystems with acidic soil.

\section{Other environmental factors}

At a global scale, depleted foliar $\delta^{15} \mathrm{~N}$ values have been found in many wet and/or cold ecosystems (Handley et al. 1999), where less $\mathrm{N}$ flows from organic to mineral $\mathrm{N}$ pools than in dry and/or hot ecosystems (Tamm 1991). However, previous experiments showed that foliar $\delta^{15} \mathrm{~N}$ values in Pinus taeda L. (Choi et al. 2005) and in oaks (Cocozza et al. 2020) were not affected by water availability. Tomlinson et al. (2016) also reported no impact of precipitation, air temperature, relative humidity, global short-wave solar radiation or wind speed on foliar or tree-ring $\delta^{15} \mathrm{~N}$ values. Site-specific soil conditions, especially $\mathrm{pH}$, which define microbial communities, may in turn play an important role in terms of plant $\delta^{15} \mathrm{~N}$ values as shown by Savard et al. (2021) who found a negative correlation between tree-ring $\delta^{15} \mathrm{~N}$ values of white spruce (Picea glauca) and soil $\mathrm{pH}$. This was explained by hydrophobic ECM fungi transferring $\mathrm{N}$ from the dissolved organic $\mathrm{N}$ pool to roots under acidic low-N conditions such as in our study area.

The foliar $\delta^{15} \mathrm{~N}$ value is an integrative signal of $\delta^{15} \mathrm{~N}$ of all plant-available $\mathrm{N}$ forms over the lifespan of a particular leaf, but it may not be representative of the soil $\delta^{15} \mathrm{~N}$ value at the time of sampling (Vallano and Sparks 2007). We attribute the overall increase in foliar $\delta^{15} \mathrm{~N}$ values with increasing proximity to the smelter as a response mainly due to stomatal uptake of $\mathrm{NO}_{\mathrm{x}}$. Changes in the soil supply of different $\mathrm{N}$ forms, higher root uptake of $\mathrm{N}$ close to the smelter or effects related to climatic factors cannot either be ruled out. For instance, the dissolved organic 
$\mathrm{N}$ compounds in the throughfall were shown to play an important role in the $\mathrm{N}$ economy of ground-layer bryophytes in northern $\mathrm{N}$-limited forest ecosystems (Salemaa et al. 2020). Therefore, organic $\mathrm{N}$ compounds, including $\mathrm{NO}_{\mathrm{x}}$-derived ${ }^{15} \mathrm{~N}$-enriched free amino acids, may be effectively circulated and retained in the studied ecosystems as suggested by the significant positive correlation between the foliar ${ }^{15} \mathrm{~N}$ and $\mathrm{N}$ values. The studies of Salemaa et al. $(2019,2020)$ support our findings on the high $\mathrm{N}$ responsiveness of the northernmost forest ecosystems.

The positive correlation between the foliar $\delta^{15} \mathrm{~N}$ value and the $\delta^{13} \mathrm{C}$ value across the studied species further suggests that the same factors are responsible for the detected changes in the foliar $\delta^{15} \mathrm{~N}$ and $\delta^{13} \mathrm{C}$ values. An increase in the $\delta^{13} \mathrm{C}$ value in $P$. sylvestris needles was also associated with an increasing $\delta^{15} \mathrm{~N}$ value near industrial enterprises (Sensula 2015) and in P. abies needles in the vicinity of a freeway (Guerrieri et al. 2009). Although the role of $\mathrm{NO}_{\mathrm{x}}$ is considered minor compared to that of $\mathrm{SO}_{2}$ in our study area, the elevated $\mathrm{NO}_{2}$ levels can also affect stomatal conductance, resulting in a decrease in $c_{i}$ and an increase in the foliar $\delta^{13} \mathrm{C}$ values irrespective of soil $\mathrm{N}$ supply (Siegwolf et al. 2001). Moreover, Savard et al. (2020) recently reported a significant impact of rising $\mathrm{NO}_{\mathrm{x}}$ emissions on tree-ring $\delta^{13} \mathrm{C}$ values in boreal spruces in the Athabasca oil sands region in Canada. The authors concluded that acidifying emissions generates true climatic-isotopic divergences that outrival any effects of rising atmospheric $\mathrm{CO}_{2}$ concentration previously reported.

\section{Conclusions}

The values of $\delta^{13} \mathrm{C}$ and $\delta^{15} \mathrm{~N}$ strongly depended on the plant species and varied even within the functional groups (i.e. evergreen and deciduous) in the studied northern N-limited forest ecosystems. The $\mathrm{SO}_{2}$ emissions in Monchegorsk are still high enough to decrease stomatal conductance as indicated by the increased foliar $\delta^{13} \mathrm{C}$ values (especially in the evergreen woody species $P$. sylvestris and E. nigrum) and thus override the potential effect on increased atmospheric $\mathrm{CO}_{2}$ concentration. The long-term deposition of $\mathrm{SO}_{2}$ and heavy metals may have affected the water economy of the plants and thus indirectly increased the foliar $\delta^{13} \mathrm{C}$ values. The emissions of $\mathrm{NO}_{\mathrm{x}}$ directly affect the foliar $\delta^{15} \mathrm{~N}$ values and/or $\mathrm{N}$ concentrations (i.e. the content of ${ }^{15} \mathrm{~N}$-enriched free amino acids) in the evergreen and deciduous trees and shrubs, while the deciduous forbs and grasses may mainly take up ${ }^{15} \mathrm{~N}$-enriched $\mathrm{NH}_{4}{ }^{+}$(and organic $\mathrm{N}$ compounds) from the soil. We call for further research on foliar $\delta^{15} \mathrm{~N}$ values in the northern forest ecosystems in which $\mathrm{N}$ cycling seems to respond to very low $\mathrm{N}$ deposition.
Supplementary Information The online version contains supplementary material available at https://doi.org/10.1007/s11356-022-19261-4.

Acknowledgements We are grateful to A. Popova for the assistance in sample collection and processing, to D. Korobushkin for arranging the analyses, and to V. Barcan and to the anonymous representative of Norilsk Nikel for information on annual levels of emissions of the Monchegorsk smelter, and to three anonymous reviewers for commenting the previous draft of the manuscript.

Author contribution SM and MVK designed the study. VZ and MVK conducted the fieldwork. MVK arranged sample processing and analysed the data. VZ prepared the illustrations. The first draft of the manuscript was written by SM and all authors commented on previous versions of the manuscript. All authors read and approved the final manuscript.

Funding Open Access funding provided by University of Turku (UTU) including Turku University Central Hospital. The study was financially supported by the Academy of Finland (project 311929) and by the University of Helsinki. The funding bodies had no effect on the design of the study and collection, analysis and interpretation of data and on writing the manuscript.

Availability of data and materials All data analysed during this study are included in this published article and its supplementary information files.

\section{Declarations}

Ethics approval and consent to participate Not applicable.

Consent for publication Not applicable.

Competing interests The authors declare no competing interests.

Open Access This article is licensed under a Creative Commons Attribution 4.0 International License, which permits use, sharing, adaptation, distribution and reproduction in any medium or format, as long as you give appropriate credit to the original author(s) and the source, provide a link to the Creative Commons licence, and indicate if changes were made. The images or other third party material in this article are included in the article's Creative Commons licence, unless indicated otherwise in a credit line to the material. If material is not included in the article's Creative Commons licence and your intended use is not permitted by statutory regulation or exceeds the permitted use, you will need to obtain permission directly from the copyright holder. To view a copy of this licence, visit http://creativecommons.org/licenses/by/4.0/.

\section{References}

Agrawal M, Deepak SS (2003) Physiological and biochemical responses of two cultivars of wheat to elevated levels of $\mathrm{CO}_{2}$ and $\mathrm{SO}_{2}$, singly and in combination. Environ Pollut 121:189-197. https://doi.org/10.1016/s0269-7491(02)002222-1

Ammann M, Siegwolf R, Pichlmayer F, Suter M, Saurer M, Brunold $\mathrm{C}$ (1999) Estimating the uptake of traffic-derived $\mathrm{NO}_{2}$ from ${ }^{15} \mathrm{~N}$ abundance in Norway spruce needles. Oecologia 118:124-131. https://doi.org/10.1007/s004420050710

Anttila P, Barrett K, Derome J, Hillamo R, Jalkanen L, Juntto S, Jurvelin J, Kubin E, Laurila T, Lindroos A-J, Lättilä H, Mäkelä T, 
Mäkinen M, Pakkanen T, Poikolainen J, Reissell A, Ryaboshapko A, Saari H, Tuovinen J-P, Virkkula A (1995) Air quality and deposition. In: Tikkanen E, Niemelä I (eds) Kola peninsula pollutants and forest ecosystems in Lapland. Finland's Ministry of Agriculture and Forestry and The Finnish Forest Research Institute, Jyväskylä, pp 29-33

Betson NR, Johannisson C, Ottosson Löfvenius M, Grip H, Granström A, Högberg P (2007) Variation in the $\delta^{13} \mathrm{C}$ of foliage of Pinus sylvestris $\mathrm{L}$. in relation to climate and additions of nitrogen: analysis of a 32-year chronology. Glob Change Biol 13:2317-2328. https:// doi.org/10.1111//j.1365-2486.2007.01431.x

Bourgeois I, Clément J-C, Caillon N, Savarino J (2019) Foliar uptake of atmospheric nitrate by two dominant subalpine plants: insights from in situ triple-isotope analysis. New Phytol 223:1784-1974. https://doi.org/10.1111/nph.15761

Brooker RW, Callaghan TV, Jonasson S (1999) Nitrogen uptake by rhizomes of the clonal sedge Carex bigelowii: a previously overlooked nutritional benefit of rhizomatous growth. New Phytol 142:35-48. https://doi.org/10.1046/j.1469-8137.1999.00384.x

Brooks JR, Flanagan LB, Buchmann N, Ehleringer JR (1997) Carbon isotope composition of boreal plants: functional grouping of life forms. Oecologia 110:301-311. https://doi.org/10.1007/s0044 20050163

Čada V, Šantrůčková H, Šantrùèek J, Kubištová L, Seedre M, Svoboda M (2016) Complex physiological response of Norway spruce to atmospheric pollution - decreased carbon isotope discrimination and unchanged tree biomass increment. Frontiers in Plant Science 7, 805. https://doi.org/10.3389/fpls.2016.00805

Choi W-J, Chang SX, Allen HL, Kelting DL, Ro H-M (2005) Irrigation and fertilization effects on foliar and soil carbon and nitrogen isotope ratios in a loblolly pine stand. For Ecol Manage 213:90-101. https://doi.org/10.1016/j.foreco.2005.03.016

Clapp LJ, Jenkin ME (2001) Analysis of the relationship between ambient levels of $\mathrm{O}_{3}, \mathrm{NO}_{2}$, and $\mathrm{NO}$ as a function of $\mathrm{NO}_{\mathrm{x}}$ in the UK. Atmos Environ 35:6391-6405. https://doi.org/10.1016/S13522310(01)00378-8

Cocozza C, Paoletti E, Mrak T, Zavadlav S, Levanic T, Kraigher H, Giovanelli A, Hoshika Y (2020) Isotopic and water relation responses to ozone and water stress in seedlings of three oak species with different adaptation strategies. Forests 11:864. https:// doi.org/10.3390/f11080864

Craine JM, Elmore AJ, Aidar MPM, Bustamante M, Dawson TE, Hobbie EA, Kahmen A, Mack MC, McLauchlan KK, Michelsen A, Nardoto GB, Pardo LH, Peñuelas J, Reich PB, Schuur EAG, Stock WD, Templer PH, Virginia RA, Welker JM, Wright IJ (2009) Global patterns of foliar nitrogen isotopes and their relationships with climate, mycorrhizal fungi, foliar nutrient concentrations, and nitrogen availability. New Phytol 183:980-992. https://doi. org/10.1111/j.1469-8137.2009.02917.x

Dawson TE, Mambelli S, Plamboeck AH, Templer PH, Tu KP (2002) Stable isotopes in plant ecology. Annu Rev Ecol Syst 33:507-559. https://doi.org/10.1146/annurev.ecolsys.33.020602.095451

Derome J, Väre H, Lindroos A-J, Nikonov V, Niska K, Ohtonen R (1995) The impact of deposition on forest soils. In: Tikkanen E, Niemelä I (eds) Kola peninsula pollutants and forest ecosystems in Lapland. Finland's Ministry of Agriculture and Forestry and the Finnish Forest Research Institute, Jyväskylä, pp 35-38

Farquhar GD, O'Leary MH, Berry JA (1972) On the relationship between carbon isotope discrimination and the intercellular carbon dioxide concentration in leaves. Aust J Plant Physiol 9:121-137

Farquhar GD, Ehleringer JR, Hubick KT (1989) Carbon isotope discrimination and photosynthesis. Annu Rev Plant Physiol Plant Mol Biol 40:503-537. https://doi.org/10.1146/annurev.pp.40. 060189.002443

Flanagan LB, Brooks JR, Ehleringer JR (1997a) Photosynthesis and carbon isotope discrimination in boreal forest ecosystems: a comparison of functional characteristics in plants from three mature forest types. J Geophys Res 102:28861-28869. https://doi. org/10.1029/97JD01235

Flanagan LB, Brooks JR, Varney GT, Ehleringer JR (1997b) Discrimination against $\mathrm{C}^{18} \mathrm{O}^{16} \mathrm{O}$ during photosynthesis and the oxygen isotope ratio of respired $\mathrm{CO}_{2}$ in boreal forest ecosystems. Global Biogeochem Cycles 11:83-98. https://doi.org/10.1029/96GB03941

Garten CT JR (1993) Variation in foliar ${ }^{15} \mathrm{~N}$ abundance and the availability of soil nitrogen on Walker Branch Watershed. Ecology 74, 2098-2113. https://www.jstor.org/stable/1940855. Accessed 4 Nov 2020

Gebauer G, Schulze E-D (1991) Carbon and nitrogen isotope ratios in different compartments of a healthy and a declining Picea abies forest in the Fichtelgebirge, NE Bavaria. Oecologia 87, 198207. https://www.jstor.org/stable/4219682. Accessed 14 Oct 2020

Gebauer G, Dietrich P (1993) Nitrogen isotope ratios in different compartments of a mixed stand of spruce, larch and beech trees and of understorey vegetation including fungi. Isot Environ Health Stud 29:35-44. https://doi.org/10.1080/10256019308046133

Geßler A, Rienks M, Rennenberg H (2002) Stomatal uptake and cuticular adsorption contribute to dry deposition of $\mathrm{NH}_{3}$ and $\mathrm{NO}_{2}$ to needles of adult spruce (Picea abies) trees. New Phytol 156:179 194. https://doi.org/10.1046/j.1469-8137.2002.00509.x

Guerrieri MR, Siegwolf RTW, Saurer M, Jäggi M, Cherubini P, Ripullone F, Borghetti M (2009) Impact of different nitrogen emission sources on tree physiology as assessed by a triple stable isotope approach. Atmos Environ 43:410-418. https://doi.org/10.1016/j. atmosenv.2008.08.042

Guerrieri R, Vanguelova E, Pitman R, Benham S, Perks M, Morison JIL, Mencuccini M (2020) Climate and atmospheric deposition effects on forest water-use efficiency and nitrogen availability across Britain. Nat Sci Rep 10:12418. https://doi.org/10.1038/ s41598-020-67562-w

Handley LL, Austin AT, Robinson D, Scrimgeour CM, Raven JA, Heaton THE, Schmidt S, Stewart GR (1999) The natural ${ }^{15} \mathrm{~N}$ abundance $\left(\delta^{15} \mathrm{~N}\right)$ of ecosystem samples reflects measures of water availability. Aust J Plant Physiol 26:185-199. https://doi.org/10. 1071/PP98146

Högberg P (1997) ${ }^{15} \mathrm{~N}$ natural abundance in soil-plant systems. New Phytol 137:179-203. https://doi.org/10.1046/j.1469-8137.1997.00808.x

Högberg P, Högberg MN, Quist ME, Ekblad A, Näsholm T (1999) Nitrogen isotope fractionation during nitrogen uptake by ectomycorrhizal and non-ectomycorrhizal Pinus sylvestris. New Phytol 142:569-576. https://doi.org/10.1046/j.1469-8137.1999.00404.x

Huang T, Zhu X, Zhong Q, Yun X, Meng W, Li B, Ma J, Zeng EY, Tao S (2017) Spatial and temporal trends in global emissions of nitrogen oxides from 1960 to 2014. Environ Sci Technol 51:79928000. https://doi.org/10.1021/acs.est.7b02235

Jung K, Gebauer G, Gehre M, Hofmann D, Weißflog L, Schüürmann G (1997) Anthropogenic impacts on natural nitrogen isotope variations in Pinus sylvestris stands in an industrially polluted area. Environ Pollut 97:175-181. https://doi.org/10.1016/S02697491(97)00053-5

Kenward MG, Roger JH (2009) An improved approximation to the precision of fixed effects from restricted maximum likelihood. Comput Stat Data Anal 53:2583-2595. https://doi.org/10.1016/j. csda.2008.12.013

Kielland K (1994) Amino acid absorption by arctic plants: implications for plant nutrition and nitrogen cycling. Ecology 75:2373-2338. https://doi.org/10.2307/1940891

Klein T, Hemming D, Lin T, Grünzweig JM, Maseyk K, Rotenberg E, Yakir D (2005) Association between tree-ring and needle $\delta^{13} \mathrm{C}$ and leaf gas exchange in Pinus halepensis under semi-arid conditions. Oecologia 144:45-54. https://doi.org/10.1007/s00442-005-0002-y

Korontzi S, Macko SA, Anderson AI, Poth MA (2000) A stable isotopic study to determine carbon and nitrogen cycling in a disturbed 
southern Californian forest ecosystem. Global Biogeochem Cycles 14:177-188. https://doi.org/10.1029/1999GB900095

Kozlov MV (2001) Snowpack changes around a nickel-copper smelter at Monchegorsk, northwestern Russia. Can J for Res 31:16841690. https://doi.org/10.1139/x01-112

Kozlov MV (2002) Changes in wind regime around a nickel-copper smelter at Monchegorsk, northwestern Russia. Int J Biometeorol 46:76-80. https://doi.org/10.1007/s00484-002-0123-5

Kozlov MV, Haukioja E (1997) Microclimate changes along a strong pollution gradient in northern boreal forest zone, in: Usó JL, Brebbia CA, Power H (eds) Ecosystems and Sustainable Development. Advances in Ecological Sciences, vol 1, pp 603-614

Kozlov MV, Zvereva EL, Zverev V (2009) Impacts of point polluters on terrestrial biota: Comparative analysis of 18 contaminated areas. Springer, Dordrecht. https://doi.org/10.1007/978-90-481-2467-1

Kwak J-H, Choi W-J, Lim S-S, Arshad MA (2009) $\delta^{13} \mathrm{C}$, $\delta^{15} \mathrm{~N}$, N concentration, and Ca-to-Al ratios of forest samples from Pinus densiflora stands in rural and industrial areas. Chem Geol 264:385-393. https://doi.org/10.1016/j.chemgeo.2009.04.002

Lavergne A, Sandoval D, Hare VJ, Graven H, Prentice IC (2020) Impacts of soil water stress on the acclimated stomatal limitation of photosynthesis: insights from stable carbon isotope data. Glob Change Biol 26:7158-7172. https://doi.org/10.1111/gcb.15364

Liebhold AM (2019) Air pollution as an experimental probe of insect population dynamics. J Anim Ecol 88:662-664. https://doi.org/ $10.1111 / 1365-2656.12992$

Littell RC, Milliken GA, Stroup WW, Wolfinger RD, Schabenberger O (2006) SAS for mixed models, 2nd ed. SAS Institute, Cary, USA

Lukina NV, Nikonov VV (1999) Pollution-induced changes in soils subjected to intense air pollution. In: Nikonov VV, Koptsik GN (eds) Acidic deposition and forest soils. Kola Science Centre, Apatity, Russia, pp 79-126 (in Russian)

Makarova TD, Rigina OA (1999) Contamination of ambient air, in: ecological atlas of Murmansk region, Moscow \& Apatity, Moscow State University \& Institute of North Industrial Ecology Problems, p. 31 (in Russian).

Manninen S, Huttunen S (2000) Response of needle sulphur and nitrogen concentrations of Scots pine versus Norway spruce to $\mathrm{SO}_{2}$ and $\mathrm{NO}_{2}$. Environ Pollut 107:421-436. https://doi.org/10.1016/ s0269-7491(99)00158-x

Manninen S, Huttunen S, Perämäki P (1997) Needle S fractions and $\mathrm{S}$ to $\mathrm{N}$ ratios as indices of $\mathrm{SO}_{2}$ deposition. Water Air Soil Pollut 95:277-298. https://doi.org/10.1007/BF02406170

Manninen S, Zverev V, Bergman I, Kozlov MV (2015) Consequences of long-term severe industrial pollution for aboveground carbon and nitrogen pools in northern taiga forests at local and regional scales. Sci Total Environ 536:616-624. https://doi.org/10.1016/ jscitotenv.2015.07.097

Marchand W, Girardin MP, Hartmann H, Depardieu C, Isabel N, Gauthier S, Boucher É, Bergeron Y (2020) Strong overestimation of water-use efficiency responses to rising $\mathrm{CO}_{2}$ in tree-ring studies. Glob Change Biol 26:4538-4558. https://doi.org/10.1111/ gcb. 151166

Martin B, Sutherland EK (1990) Air pollution in the past recorded in width and stable carbon isotope composition of annual growth rings of Douglas-fir. Plant, Cell Environ 13:839-844. https://doi. org/10.1111/j.1365-3040.1990.tb01101.x

Martin B, Bytnerowicz A, Thorstenson YR (1988) Effects of air pollutants on the composition of stable carbon isotopes, $\delta^{13} \mathrm{C}$, of leaves and wood, and on leaf injury. Plant Physioliology 88:218-223. https://doi.org/10.1104/pp.88.1.218

Medrano H, Tomás M, Martorell S, Flexas J, Hernández E, Rosselló J, Pou A, Escalona J-M, Bota J (2015) From leaf to whole-plant water efficiency (WUE) in complex canopies: limitations of leaf WUE as a selection target. The Crop Journal 3:220-228. https:// doi.org/10.1016/j.cj.2015.04.002
Michelsen A, Quarmby C, Sleep D, Jonasson S (1998) Vascular plant ${ }^{15} \mathrm{~N}$ natural abundance in heath and forest tundra ecosystems is closely correlated with presence and type of mycorrhizal fungi in roots. Oecologia 115:406-418. https://doi.org/10.1007/s0044 20050535

Ministry of Natural Resources and Ecology in the Murmansk Oblast, 2020. Report on the state and protection of the environment of the Murmansk oblast in 2019. Murmansk (in Russian). Available at: https://gov-murman.ru/region/environmentstate/. Accessed 4 Nov 2021

Morikawa H, Higaki A, Nohno M, Takahashi M, Kamada M, Nakata M, Toyohara G, Okamura Y, Matsui K, Kitani S, Fujita K, Irifune K, Goshima N (1998) More than a 600-fold variation in nitrogen dioxide assimilation among 217 plant taxa. Plant, Cell Environ 21:180-190. https://doi.org/10.1046/j.1365-3040.1998.00255.x

Muller B, Touraine B, Rennenberg H (1996) Interaction between atmospheric and pedospheric nitrogen nutrition in spruce (Picea abies L. Karst.) seedlings. Plant, Cell Environ 19:345-355. https:// doi.org/10.1111/j.1365-3040.1996.tb00257.x

Nadelhoffer KJ, Fry B (1988) Controls on natural nitrogen-15 and carbon-13 abundances in forest soil organic matter. Soil Sci Soc Am J 52:1633-1640. https://doi.org/10.2136/sssaj1988.0361599500 $5200060024 x$

Nadelhoffer KJ, Fry B (1994) Nitrogen isotope studies in forest ecosystems. In: Lajtha K, Michener R (eds) Stable isotopes in Ecology and Environmental Science. Blackwell Scientific Publication, Boston, MA, USA, pp 23-44

Nordin A, Näsholm T, Ericson L (1998) Effects of simulated N deposition on understorey vegetation of boreal coniferous forest. Funct Ecol 12:691-699. https://doi.org/10.1046/j.1365-2435.1998. 00240.x

O'Leary MH (1981) Carbon isotope fractionation in plants. Phytochemistry 20:553-567. https://doi.org/10.1016/0031-9422(81) 85134-5

Ozolincius R, Stakenas V, Serafinaviciute B (2005) Meteorological factors and air pollution in Lithuanian forests: possible effects on tree condition. Environ Pollut 137:587-595. https://doi.org/10. 1016/j.envpol.2005.01.044

Pardo LH, Templer PH, Goodale CL, Duke S, Groffman PM, Adams MB, Boeckx P, Boggs J, Campbell J, Colman B, Compton J, Emmett B, Gundersen P, Kjønaas J, Lovett G, Mack M, Magill A, Mbila M, Mitchell MJ, McGee G, McNulty S, Nadelhoffer K, Ollinger S, Ross D, Rueth H, Rustad L, Schaberg P, Schiff S, Schleppi P, Spoelstra J, Wessel W (2006) Regional assessment of $\mathrm{N}$ saturation using foliar and root $\delta^{15} \mathrm{~N}$. Biogeochemistry 80:143171. https://doi.org/10.1007/s10533-006-9015-9

Peterson BJ, Fry B (1987) Stable isotopes in ecosystem studies. Annu Rev Ecol Syst 18:293-320

Polley HW, Johnson HB, Marino BD, Mayeux HS (1993) Increase in $\mathrm{C} 3$ plant water-use efficiency and biomass over Glacial to present $\mathrm{CO}_{2}$ concentrations. Nature 361:61-64. https://doi.org/10.1038/ $361061 \mathrm{a} 0$

Pornon A, Boutin M, Lamaze T (2019) Contribution of plant species to the high $\mathrm{N}$ retention capacity of a subalpine meadow undergoing elevated N deposition and warming. Environ Pollut 245:235-242. https://doi.org/10.1016/j.envpol.2018.10.027

Redling K, Elliott E, Bain D, Sherwell J (2013) Highway contributions to reactive nitrogen deposition: tracing the fate of vehicular $\mathrm{NO}_{\mathrm{x}}$ using stable isotopes and plant biomonitors. Biogeochemistry 116:261-274. https://doi.org/10.1007/s10533-013-9857-x

Reich PB, Walters MB, Ellsworth DS (1997) From tropics to tundra: global convergence in plant functioning. Proc Natl Acad Sci USA 94:13730-13734. https://doi.org/10.1073/pnas.94.25.13730

Reimann C, Äyräs M, Chekushin V, Bogatyrev I, Boyd R, de Caritat P, Dutter R, Finne TE, Halleraker JH, Jæger Ø, Kashulina G, Lehto O, Niskavaara H, Pavlov V, Räisänen ML, Strand T, Volden 
T (eds) (2011) Environmental geochemical atlas of the Central Barents Region. Geological Survey of Norway (NGU), pp 743

Roth M, Günther K, Michiels H-G, Puhlmann H, Sucker C, Hauck M (2021) Nitrogen deposition is positively correlated to foliar nitrogen content in vaccinium myrtillus and other understorey species in temperate forests on acid soil. Acta Oecologica 110:103696. https://doi.org/10.1016/j.actao.2020.103696

Rounick JS, Winterbourn MJ (1986) Stable carbon isotopes and carbon flow in ecosystems. Bioscience 36:171-177. https://doi.org/10. 2307/1310304

Ruotsalainen AM, Markkola A, Kozlov MV (2007) Root fungal colonisation in Deschampsia flexuosa: effects of pollution and neighbouring trees. Environ Pollut 147:723-728. https://doi.org/10. 1016/j.envpol.2006.09.004

Ruotsalainen AL, Markkola AM, Kozlov MV (2009) Mycorrhizal colonisation of mountain birch (Betula pubescens ssp. czerepanovii) along three environmental gradients: does life in harsh environments alter plant-fungal relationships? Environ Monit Assess 148:215-232. https://doi.org/10.1007/s10661-007-0152-y

Salemaa M, Lindroos A-J, Merilä P, Mäkipää R, Smolander A (2019) $\mathrm{N}_{2}$ fixation associated with the bryophyte layer suppressed by low levels of nitrogen deposition in boreal forests. Sci Total Environ 653:995-1004. https://doi.org/10.1016/j.scitotenv.2018.10.364

Salemaa M, Kieloaho A-J, Lindroos A-J, Merilä P, Poikolainen J, Manninen S (2020) Forest mosses sensitively indicate nitrogen deposition in boreal background areas. Environ Pollut 261:114054. https://doi.org/10.1016/j.envpol.2020.114054

SAS Institute, 2009. SAS/Stat. User's guide, version 9.2. SAS Institute, Cary, NC.

Savard MM (2010) Tree-ring stable isotopes and historical perspectives on pollution - an overview. Environ Pollut 158:2007-2013. https://doi.org/10.1016/j.envpol.2009.11.031

Savard MM, Begin C, Parent M, Smirnoff A, Marion J (2004) Effects of smelter sulfur dioxide emissions: a spatiotemporal perspective using carbon isotopes in tree rings. J Environ Qual 33:13-26. https://doi.org/10.2134/jeq2004.1300

Savard MM, Begin C, Marion J (2020) Response strategies of boreal spruce trees to anthropogenic changes in air quality and rising $\mathrm{pCO}_{2}$. Environ Pollut 261:114209. https://doi.org/10.1016/j. envpol.2020.114209

Savard MM, Martineau C, Laganière J, Bégin C, Marion J, Smirnoff A, Stefani F, Bergeron J, Rheault K, Paré D, Séguin A (2021) Nitrogen isotopes in the soil-to-tree continuum - tree rings express the soil biogeochemistry of boreal forests exposed to moderate airborne emissions. Sci Total Environ 780:146581. https://doi. org/10.1016/j.stoten.2021.146581

Schimel JP, Chapin FS III (1996) Tundra plant uptake of amino acids and NH4+ nitrogen in situ: plants compete well for amino acid $\mathrm{N}$. Oecologia 77:2142-2147. https://doi.org/10.2307/2265708

Schulze ED (1989) Air pollution and forest decline in a spruce (Picea abies) forest. Science 244:776-783. https://doi.org/10.1126/scien ce.244.4906.776

Schulze ED, Chapin FS III, Gebauer G (1994) Nitrogen nutrition and isotope differences among life forms at the northern treeline of Alaska. Oecologia 100:406-412. https://doi.org/10.1007/BF003 17862

Sensula BM (2015) Spatial and short-temporal variability of $\delta^{13} \mathrm{C}$ and $\delta^{15} \mathrm{~N}$ and water-use efficiency in pine needles of the three forests along the most industrialized part of Poland. Water Air Soil Pollut 226:362. https://doi.org/10.1007/s11270-015-2623-z

Siegwolf RTW, Matyssek R, Saurer M, Maurer S, Günthardt-Goerg M, Schmutz P, Bucher JB (2001) Stable isotope analysis reveals differential effects of soil nitrogen and nitrogen dioxide on the water use efficiency in hybrid poplar. New Phytol 149:233-246. https://doi.org/10.1046/j.1469-8137.2001.00032.x
Stulen I, Pérez-Soba M, De Kok LJ, Van der Eerden L (1998) Impact of gaseous nitrogen on plant functioning. New Phytol 139:61-70. https://doi.org/10.1046/j.1469-8137.1998.00179.x

Tamm CO (1991) Nitrogen in terrestrial ecosystems: questions of productivity, vegetational changes, and ecosystem stability. SpringerVerlag, Berlin.

Tan J, Fu JS, Dentener F, Sun J, Emmons L, Tilmes S, Flemming J, Takemura T, Bian H, Zhu Q, Yang C-E, Keating T (2018) Source contributions to sulfur and nitrogen deposition - an HTAP II multi-model study on hemispheric transport. Atmos Chem Phys 18:12223-12240. https://doi.org/10.5194/acp-18-12223-2018

Tomlinson G, Buchmann N, Siegwolf R, Weber P, Thimonier A, Pannatier EG, Schmitt M, Schaub M, Waldner P (2016) Can treering $\delta^{15} \mathrm{~N}$ be used as a proxy for foliar $\delta^{15} \mathrm{~N}$ in European beech and Norway spruce? Trees 30:627-638. https://doi.org/10.1007/ s00468-015-1305-1

Vallano DM, Sparks JP (2007) Foliar $\delta^{15} \mathrm{~N}$ values as indicators of foliar uptake of atmospheric nitrogen pollution. Terrestrial Ecology 1:93-109. https://doi.org/10.1016/S1936-7961(07)01007-X

Veselkin DV, Chashchina OE, Kuyantseva NB, Mumber AG (2019) Stable carbon and nitrogen isotopes in woody plants and herbs near the large copper smelting plant. Geochem Int 57:575-582. https://doi.org/10.1134/S0016702919050124

Vorobeichik EL, Kozlov MV (2012) Impact of point polluters on terrestrial ecosystems: methodology of research, experimental design, and typical errors. Russ J Ecol 43:89-96

Wagner W, Wagner E (2006) Influence of air pollution and site conditions on trends of carbon and oxygen isotope ratios in tree ring cellulose. Isot Environ Health Stud 42:353-365. https://doi.org/ 10.1080/10256010600991078

Wellburn AR (1990) Why are atmospheric oxides of nitrogen usually phytotoxic and not alternative fertilizers? New Phytol 115:395429. https://doi.org/10.1111/j.1469-8137.1990.tb00467.x

Whitfield J (2007) Underground networking. Nature 449:136-138. https://doi.org/10.1038/449136a

Winner EW, Atkinson CJ (1986) Absorption of air pollution by plants, and consequences for growth. Trends Ecol Evol 1:15-18. https:// doi.org/10.1016/0169-5347(86)90061-3

Xu Y, Xiao H (2017) Concentrations and nitrogen isotope compositions of free amino acids in Pinus massoniana (Lamb.) needles of different ages as indicators of atmospheric nitrogen pollution. Atmos Environ 164:348-359. https://doi.org/10.1016/j.atmosenv. 2017.06.024

$\mathrm{Xu}$ Y, Xiao H, Wu D (2019) Traffic-related dustfall and $\mathrm{NO}_{\mathrm{x}}$, but not $\mathrm{NH}_{3}$, seriously affect nitrogen isotopic compositions in soil and plant tissue near the roadside. Environ Pollut 249:655-665. https://doi.org/10.1016/j.envpol.2019.03.074

Zhong Q, Shen H, Yun X, Chen Y, Ren Y, Xu H, Shen G, Du W, Meng J, Li W, Ma J, Tao S (2020) Global sulfur dioxide emissions and the driving forces. Environ Sci Technol 54:6508-6517. https:// doi.org/10.1021/acs.est.9b07696

Zhu Rg, Xiao H-Y, Zhang Z, Lai Y (2018) Compound-specific $\delta^{15} \mathrm{~N}$ composition of free amino acids in moss as indicators of atmospheric nitrogen sources. Sci Rep 8:14347. https://doi.org/10.1038/ s41598-018-32531-x

Publisher's Note Springer Nature remains neutral with regard to jurisdictional claims in published maps and institutional affiliations. 